\title{
The ESCO Formula as Support for Public and Commercial Energy Projects in Poland
}

\author{
Joanna Kurowska-Pysz $^{1}$ (D) and Grzegorz Kunikowski ${ }^{2, *(D)}$ \\ 1 Faculty of Applied Sciences, WSB University, 41-300 Dabrowa Górnicza, Poland; jkurowska@wsb.edu.pl \\ 2 Faculty of Management, Warsaw University of Technology, 00-661 Warszawa, Poland \\ * Correspondence: grzegorz.kunikowski@pw.edu.pl
}

Citation: Kurowska-Pysz, J.; Kunikowski, G. The ESCO Formula as Support for Public and Commercial Energy Projects in Poland. Energies 2021, 14, 8098. https://doi.org/10.3390/en14238098

Academic Editor: Vincenzo Bianco

Received: 25 October 2021

Accepted: 1 December 2021

Published: 3 December 2021

Publisher's Note: MDPI stays neutral with regard to jurisdictional claims in published maps and institutional affiliations.

Copyright: (C) 2021 by the authors. Licensee MDPI, Basel, Switzerland. This article is an open access article distributed under the terms and conditions of the Creative Commons Attribution (CC BY) license (https:/ / creativecommons.org/licenses/by/ $4.0 /)$.

\begin{abstract}
The formula of engaging an energy service company (ESCO) in Poland is not a new form of accounting for investments in improving energy efficiency. The results of our survey confirm that many entities still lack sufficient knowledge about this subject. The research problem this paper is concerned with is the conditions of applying the ESCO formula (a model of investment financing with the participation of a specialised company) to support local government units and enterprises in energy-industry project development. For the purpose of this study, the research questions were formulated to analyse of the following issues: the reasons for interest in the ESCO formula and the sources of knowledge about this solution; activities and other factors that can increase or reduce interest in the ESCO formula; services in terms of ESCO formula implementation; the attractiveness of alternative instruments for financing energy industry projects, the benefits of using the ESCO formula and the influence of current and future target groups on ESCO formula development in Poland. This paper, therefore aims to recognise the conditions under which the ESCO formula can be applied by local government units and enterprises implementing energy industry projects in Poland. The research problem was solved using a triangulation of research methods: empirical qualitative research (desk research analysis, individual in-depth interviews, computer-assisted web interview (CAWI) survey, and focus group interviews) and one of the foresight methods (an expert panel). The research revealed that the lack of knowledge amongst local government units and enterprises with regard to the ESCO formula, although not unique to Poland, is insufficient to explain the low level of interest in this solution. One of the key conclusions is the need to educate local government units and enterprises on energy efficiency. This is vital to arouse their interest in the more complex ESCO implementation solutions that they have not yet investigated. Furthermore, by following and analysing the project implementation process in the ESCO formula, we can conclude that the risk generated is primarily on the part of the energy service company itself. For this reason, it is doubtful that energy service companies will invest the equity necessary to develop this challenging market. Based on the research conclusions, we indicate some recommendations that the government and related public institutions should consider in order to boost this market and support ESCO companies.
\end{abstract}

Keywords: ESCO; EPC; energy efficiency; private sector; public sector

\section{Introduction}

Energy efficiency (EE) plays an essential role in accelerating clean energy transitions and achieving global climate and sustainability goals [1,2]. Therefore, it has an important place in the public policy agenda of most developed countries as they make great efforts to reduce energy consumption through climate and energy policies, programmes and targets $[3,4]$.

In terms of EE, we have a related energy service company (ESCO) formula which is a solution that considers both energy technologies and the sharing of technological, financial and legal risks [5]. In literature, the acronym ESCO refers both to specialised companies [6] known as ESCOs and to a business model [5]. Reference to ESCO is also made in literature 
to describe an EE project delivery model. In addition to the above-mentioned options there are alternatives such as public-private partnership (PPP) and energy performance contracts (EPC) which provide other procurement models [7]. For the purpose of this research paper, we use a broader definition of the ESCO formula that encompasses all of the meanings above (hereafter ESCO or ESCO formula) and we refer to a model of investment financing mechanism using EPC contracts with the participation of a specialised company.

The value of the global ESCO market was estimated at USD 28.6 billion in 2017 [8] while the European ESCO market was in the region of USD 2.7 billion in 2015 [3,9]. According to ESCO market development research [10], the Polish market experienced a slow increase in the period 2015-2018. In 2020, there were 20 companies registered as energy service providers [11].

For local government units, the spending of funds under the operational programs of individual voivodeships is a priority.

A detailed description of the priority axes clearly indicates that in the thermo-modernisation of public utility and residential buildings, the reduction of low emissions and energy-saving outdoor lighting (streets, parks, squares), there is a preference for investments carried out using the ESCO formula as can been seen in the Mazowieckie Voivodeship [12]. The same is true for other voivodeships.

Therefore, the implementation of investments using the ESCO formula means the applicant is given preference. This preference confirms that the voivodeship authorities in Poland took the ESCO formula into account when preparing the rules for spending EU funds. Currently, the use of the ESCO formula facilitates the financing of the investment.

The main barrier to the ESCO market in Poland is that the legal framework is still ambiguous, and further review is seen as necessary by market actors. In addition, a lack of trust is distressing the market due to the scarcity of appropriate financing and lack of good examples to counterbalance the ample information about bad examples. Transaction costs are high as a result, and energy prices are relatively low [10].

Several studies have analysed the drivers and barriers of the ESCO market and the use of ESCO in general $[9,13,14]$ and in the public domain $[5,15,16]$.

The risk of projects implemented using the ESCO formula has also been described in literature [14,17-19]. Barrier assessments and recommendations for Poland are general [20-22] and formulated as part of international comparative analyses. In our opinion, due to the growing importance of local energy projects, these barriers require in-depth study.

This research paper aims to recognise the conditions necessary to apply the ESCO formula as a solution to support local government units and enterprises in the field of energy industry project development and implementation in Poland. The authors also defined three sub-goals related to:

- the identification of factors that raise the interest of Polish local government units and enterprises in implementing energy industry projects in the ESCO formula;

- the identification of solutions under which energy projects financed using the ESCO formula can be implemented in Poland;

- the preparation of recommendations to the Polish Ministry of Energy, regarding ESCO formula improvement and development in Poland.

To solve the research problem, the research questions were formulated, and the following issues were analysed: the reasons for interest in the ESCO formula and the sources of knowledge about its solution; activities and other factors that can increase or decrease interest in the ESCO formula; services in terms of the ESCO formula implementation; the attractiveness of different instruments for financing energy industry projects and the benefits resulting from using this formula, as well as the influence of current and future target groups on ESCO formula development in Poland. Growing interest in public and commercial energy projects using EU funds in 2021-2027 is also a driving force. Investment is typically financed by subsidies and either private funds or a commercial loan and private funds. This approach increases long-term debt, thus limiting interest from public sector investors. An equally important challenge is the technical knowledge about energy efficiency 
and the risk involved in maintaining energy parameters. Using the ESCO formula, expert knowledge is not required from the investor. Similarly, the risk is transferred to the ESCO, which guarantees and accounts for energy effects through EPC contracts. Poland needs to make use of the ESCO formula because traditional and more widespread investment financing models, those based on subsidies for example, can no longer be maintained (European funds are shrinking). Moreover, investments that are considered likely to produce returns should slowly move away from public funds. The third reason is that some local government units and enterprises do not have funds necessary to contribute to EU projects or projects based on redeemable loans. Therefore, the support of ESCOs is an alternative model for implementing such projects.

Basing on a triangulation of research methods [23], the research problem was solved using empirical qualitative research (desk research analysis, in-depth individual interviews, computer assisted web interview (CAWI) survey, focus group interviews), as well as one of the foresight methods (an expert panel).

The study was undertaken with the agreement of the Polish Ministry of Energy [24], which commissioned and funded the research.

The remainder of the paper is organised as follows: in Section 2, we present the literature review. In the Section 3, research methods and the design of the empirical research are outlined. In Section 4 , we present the results. Section 5 provides a discussion and presents the limitations of our study. Finally, the paper ends with Section 6, where we present our conclusions and recommendations.

The article's novelty is to examine the assessments of the ESCO formula in Poland from the perspective of stakeholders representing the public and commercial sectors. The publications describing the current problems of Poland are international comparative analyses. Publications on ESCO in Poland are from the beginning of the 21st century and there have been very few since 2010. This article presents the results of current empirical research in which various points of view of enterprises and local government units were examined on the basis of a triangulation of research methods.

\section{Literature Review}

This article explains ESCO as a model investment financing mechanism (referred to forthwith as the "ESCO formula" or "ESCO"), in which one of the parties is a specialised company providing energy services based on the energy performance contracts (EPC). The two most common types of EPC are referred to as a (1) shared savings or (2) guaranteed savings model [8].

In essence, the ESCO formula is a comprehensive approach to financing investment projects, including financing using EU funds [7]. Other innovative methods of financing energy projects in the context of the challenges of the energy transformation are also used, such as energy cooperatives, analysed by Yildiz et.al [25], or crowdfunding models as the philanthropic-crowdfunding partnership model proposed by Ari and Koc [26].

Due to the complexity of ESCO projects in the public sector, the simplest and most popular projects are lighting modernisation [27] and energy efficiency in the municipal and housing sectors $[6,28,29]$. Advanced solutions concern the generation of energy for own needs-in CHP installations [19] for example. Advanced energy projects the industrial sector have also been realised using the ESCO formula.

The definition of EPCs depends on the country [30]. Common to all EPCs, however, is the fact that they are drawn for a specific period and detail the delivery of specific energy effects, monitored and linked to financial settlements.

In the Energy Efficiency Directive 2012/27/EU [31], EPC is defined as a contractual arrangement between the beneficiary and the provider of an energy efficiency improvement measure, verified and monitored during the whole term of the contract, where investments (work, supply or service) in that measure are paid for at a contractually agreed level of energy efficiency improvement or other agreed energy performance criterion, such as financial savings. 


\subsection{Drivers of Interest in the ESCO Formula}

To stimulate the development of the energy services market using the ESCO formula, governments use incentives and drivers. Trianni et al. [13] classify drivers for development as follows: regulatory, economic, informative and vocational, distinguishing external and internal drivers for each category. The importance of public financing is emphasised which, apart from commercial financing, constitutes essential support, especially for small and medium-sized enterprises (SMEs) [13]. Bertoldi and Boza-Kiss [9] used the following categorisation in their international research: (1) legal and political; (2) procedural factors and tools; (3) financing; (4) information and awareness; and (5) structural and marketrelated changes. Those areas of the research that concerned the situation in Poland, white certificates are identified as the legal driver.

To stimulate private sector investments and promote energy efficiency through publicprivate partnership arrangements, the public sector uses private companies, that is to say, an energy service company (ESCO) [6].

\subsection{Risks and Barriers in the Application of ESCO Formula}

Barriers to implementing the ESCO formula have been well researched and described by scholars using qualitative research methods $[9,13,15,32,33]$.

ESCO solutions raise numerous concerns and risks [34] and encounter various barriers. Lee et al. used the following risk categorisation: economic; financial; project design; installation; technology; operational, and measurement and verification [18]. GarbuzovaSchlifter and Madlener [17] distinguished the following risk factors: project preparation and execution phases; contractual; technical and operational; financial; clients; human and behavioural; political and regulatory, and market.

The barriers are: legal; unfamiliarity with ESCO contracting; public debt; ownership issues; ownership of energy savings; competition from subsidies; reluctance to enter into PPP (public-private partnership); in-house implementation of projects; reluctance among the company's engineers, and decision-making processes [22]. Other researchers classify the barriers to information and awareness: legislative and accounting; behavioural; market and external; financial, and technical and administrative [3]. According to [1], the main barriers in developing countries are institutional and financial.

Bertoldi and Boza-Kiss indicate the problem of the cost of projects implemented using the ESCO formula to the public debt by local governments. This approach follows the EUROSTAT methodology and places restrictions in EU legislation on the requirements of the budgetary frameworks of the Member States. Although the text of the legislation is ambiguous, almost all countries have interpreted the EUROSTAT methodology as a barrier to ESCO projects, including Slovakia, the Czech Republic, and Poland. Others, such as Spain did not take a stand. The second problem was the limited liquidity and creditworthiness of public administrations, especially following the financial crisis [9].

Another barrier indicated in literature is the limited knowledge of the possibilities of financing energy efficiency projects in the form of ESCOs amongst potential beneficiaries [2]. Such barriers have been ling since identified [35]. On the other hand, current research shows more detailed knowledge needs have been formulated-the publishing of model EPC contracts [27], the dissemination of good examples, the modification of tender procedures [14,18] and public-private partnership [3].

Stagnation and decline must be taken into account, particularly in developing markets. For example, in 2010, the ESCO market was perceived as a fast-growing market in Sweden [35]. However, nine years later in 2019, it was noted in an international study that it was the only market in Europe to record a steady decline [10].

It is worth paying attention to the beneficiaries' expectations that the ESCO formula will produce visible savings immediately while also avoiding risks [36]. Even though this example concerns a business model of heat sales in Finland, this expectation is universal and demonstrates the need to create business models which promote risk-taking by companies that provide ESCO services. 


\subsection{ESCO in Poland}

The primary legal Act for the activities of ESCOs is the Energy Efficiency Act [37]. Due to the financing of crucial provincial funding programmes that directly indicate the formula of ESCO as an acceptable form of co-financing of regional operational programmes $[38,39]$ and regional plans for a low-carbon economy, such as in the Polish city of Kielce [40]. The majority of services provided by ESCO companies in Poland involve advice/audit services (the most popular and most frequently provided), energy efficiency in buildings, district heating and cooling, lighting, CHP, energy generation and distribution [10].

The Polish ESCO market is described in the literature, but it is not a popular topic. Most of the information available comes from international review reports. In 2017, it was identified as a market in the initial stage of development in 2013-2016, and it was in a state of slow growth [3].

In 2014, actions promoting the development of this market were recommended including the continuation of the creation of dedicated funds to support the use of the ESCO formula. Central administration support was also recommended in the field of formal solutions for ESCO business, a knowledge development platform and the dissemination of sample documents, in particular EPC contracts, and criteria for selecting ESCOs in tenders [41]. The ex ante analysis also formulated recommendations for developing ESCOs and using EPC contracts as financial instruments to be used in the Operational Program Infrastructure and Environment 2014-2020 [20]. According to the EU Joint Research Centre [10], respondents to a survey conducted in Poland indicated the following barriers: insufficient promotion of energy services, mistrust, and the incompatibility of ESCOs with other financial systems.

The amendment of the Energy Efficiency Act [37] should be considered significant, where provisions were introduced to directly facilitate the ESCO formula in local governments.

From the point of view of the dynamics of the development of the ESCO services market in Poland, the slow growth should be noted. In 2005, there were eight such companies [3]; by 2020 this number had increased, but only to twenty [11].

The drivers of the energy services market include dynamic development of energy technologies (including smart grids), the relationship of the price of construction services and materials to the prices of energy carriers, the growing energy awareness of end-users, and the involvement of non-energy companies such as telecommunication operators, in the energy services market. It is expected that energy companies will continue to diversify their portfolio of services seemingly not related to their core operations [10].

In the literature analysis, we can say that in general the ESCO topic is well described in the international literature. According to the authors, the conclusions are universal and relevant for other developed and developing countries.

As mentioned above, the topic of the ESCO market in Poland is not covered in scientific studies but is present in industry reports. There are, however, visible actions aimed at popularising the recommended mechanism in the official funding rules for energy efficiency projects. The experiences in implementing energy efficiency investments in public utility institutions are questionable in terms of the results achieved and the resources spent. The results of the audit of energy efficiency investments made in public-use organisations by the Polish Supreme Audit Office [42] proved that for the audited facilities, the average basic investment return period was 65 years. This example proves insufficient knowledge or imperfect procedures in which indicators are not used to assess the energy effect when planning investments.

Therefore, the authors identify a gap in research concerning the conduct and publication of scientific results of ESCO market research in Poland regarding the state of market development, current barriers, and identification of the awareness of the mechanism among public and commercial recipients of ESCO services. 


\section{Research Approach and Methodology}

\subsection{Research Assumptions and Design}

As shown above, the realisation of energy industry projects in local government units and enterprises is often a challenge and even a problem, resulting in low motivation to undertake such projects. The reasons for this situation certainly include the difficulty of selecting appropriate sources of financing for those projects, often combined with poor preparation and qualification for managing them and the need to accept deferred profit or to obtain dominant environmental and social profits with only a small margin of economic gain from such projects.

In principle, in addition to direct financial resources, the use of both EU funds and repayable and non-repayable national public funds for energy industry projects is recommended. This is, however, connected with numerous limitations described in literature, such as bureaucratic procedures, a long waiting period for project evaluation, restrictive conditions of project accounting, the risk of having to return the grant, a lack of funds for investor contribution, limited eligibility of costs and activities that can be financed from the grant. Moreover, when it comes to externally financed repayable debt (e.g., a loan or credit), the main problem is often the inability to demonstrate adequate collateral for the debt or the need to include it in the financial statements as an additional encumbrance on the entity's liquidity [43-45].

Taking the identified limitations concerning the implementation of the described forms of financing of the energy industry projects by local government units and enterprises into account, in this article, the authors formulated a research problem concerning the conditions of applying the ESCO formula as a solution supporting those entities in terms of energy industry project development.

To solve the research problem, the authors defined two research questions:

1. What factors influence the interest of local government units and enterprises in implementing energy industry projects in the ESCO formula in Poland?

2. What solutions can support the implementation of the ESCO formula in Poland?

To answer the first research questions, the authors analysed:

- $\quad$ the reasons for the interest of local governments units and enterprises in the ESCO formula;

- $\quad$ the sources of knowledge about its solution;

- the activities and other factors that can increase or decrease interest in the ESCO formula.

To answer the second research questions the authors analysed:

- $\quad$ the services offered for the local governments' units and enterprises in terms of the ESCO formula implementation;

- $\quad$ the attractiveness of different instruments financing energy industry projects;

- $\quad$ the benefits for the local government units and enterprises resulting from using the ESCO formula;

- $\quad$ the influence of current and future target groups on the ESCO formula development in Poland.

Based on the above research questions, the authors defined the paper's goal concerning recognising the conditions for applying the ESCO formula by local government units and enterprises implementing energy industry projects in Poland.

Additionally, the authors formulated three sub-goals:

1. The identification of factors influencing the interest of Polish local government units and enterprises in implementing energy industry projects in the ESCO formula.

2. The identification of solutions under which energy projects financed using the ESCO formula can be implemented in Poland.

3. Defining the Polish Ministry of Energy recommendations, useful for the ESCO formula improvement and development in Poland. 


\subsection{The Research Procedure}

To solve the research problem and achieve the research goals, the authors based on a triangulation of the research methods [23]. Triangulation uses several research techniques to analyse a given issue to increase the credibility and accuracy of the results, and as a result, give a thorough understanding of the phenomenon under study. They conducted the empirical qualitative research and applied the foresight method [1]. Such diverse perspectives justify approaches similar to those adopted by authors of other studies regarding ESCO $[3,18,27,46,47]$.

The authors also realised the appropriate desk research analysis based on the literature. They found data concerning the documentation of the implementation of European programmes financing projects in the field of energy and analytical reports on the implementation of the ESCO formula in Poland and abroad.

In terms of qualitative research, a combination of the following research techniques was applied:

- Direct/online in-depth individual interviews (IDI) realised according to the scenario, including open questions. The in-depth individual interview is pervasively applied in qualitative research because it is versatile across a range of study topics, adaptable in challenging field conditions, and excellent for not just providing information but also for generating understanding as well [48]. There are some examples of the application of in-depth individual interviews in investigating social barriers to the adoption of smart homes [49]; stakeholder analysis of energy performance contract models [50].

- CAWI surveys (computer-assisted web interview) based on standardised questionnaires (the close questions, single choice or multiple choice). CAWI surveys produce savings on direct costs (logistics and interviewers) concerning phone or Internet interviews, while at the same time providing a high (or higher) level of quality in terms of sampling procedures, data collection, field monitoring, and data processing. There is an example of applying an extensive CAWI survey in the research concerning the mobility data across the EU 28 members [51].

- Focus group interview (FGI) conducted as a structured and moderated discussion in which six people participated, realised according to the scenario defining the conversation goals and guidelines for the moderator. Focus group interviews are ubiquitous in social-behavioural sciences, public policy, and political research [48], the example of application is given above [50].

In terms of the foresight method, the authors applied a panel of experts. The expert panel is one of the key foresight methods, carried out in the form of a panel discussion with the participation of a wide group of specialists in a given field. During such a meeting, various positions are confronted, knowledge is accumulated, and, for example, recommendations and proposed solutions are developed [52]. An expert panel was applied in research focused on zero-emission vehicle technologies recognition [53]. The authors organised the panel to verify the validity of the detailed findings resulting from other research techniques but also to confirm the final conclusion and recommendations.

The qualitative research was conducted between 2017 and 2019. It covered a sample of 6 experts and 68 entities implementing or intending to implement projects based on the ESCO formula, including:

- 42 local government units;

- 21 enterprises;

- 5 institutions that provide financial support for energy projects.

The selection of the research sample was non-random. We selected the representatives of the respective target groups (local government units and companies) in two ways:

- the authors conducted desk research and social media analysis to recognize what entities deal with ESCO; those entities were invited to participate in the research as respondents; 
- the authors used the mailing list prepared by the Ministry of Energy; those entities were invited to participate in the research as respondents.

In total, we found about 75 representatives of the target groups, but not all we available to participate in the research (in-depth individual interviews, CAWI surveys and focus group interviews).

The distribution of entities covered by the study on the map of Poland is presented in Figure 1 below.

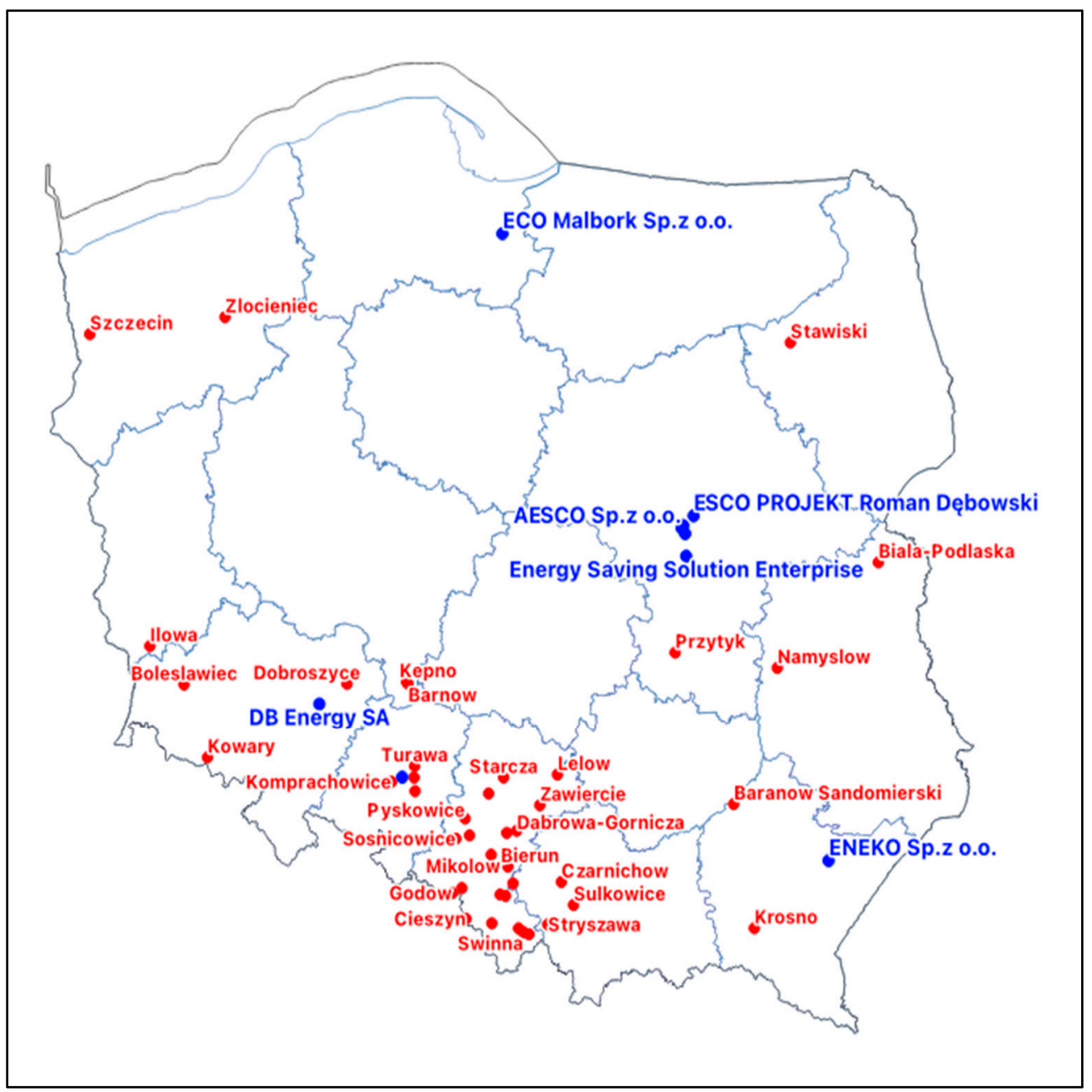

Figure 1. The distribution of entities covered by the study on the map of Poland (local government units-in red, enterprises-in blue).

The research procedure was carried out in four stages as presented in Table 1.

Based on the scenarios organized according to the research questions, the authors conducted both in-depth interviews and focus group interviews, recording all of them. The authors then prepared transcriptions and analysed the scope of the text based on the following procedure:

- $\quad$ comparing answers to the same questions;

- grouping statements into thematic threads;

- $\quad$ evaluating individual statements within the same thematic threads;

- $\quad$ identifying key words, similarities and differences in statements and relating them to the entire context of the research;

- formulation of partial conclusions;

- $\quad$ formulation of final conclusions. 
Table 1. The research procedure. Source: own elaboration.

\begin{tabular}{|c|c|c|}
\hline Stage & Target Group and Sample & Outcome \\
\hline $\begin{array}{l}\text { I. } \\
\text { In-depth } \\
\text { individual } \\
\text { interviews }\end{array}$ & $\begin{array}{l}\text { - } \quad 3 \text { institutions that provide financial } \\
\text { support for energy project } \\
\text { - } \quad 3 \text { local government units } \\
\text { - } \quad 3 \text { enterprises }\end{array}$ & $\begin{array}{l}\text { Identification of general } \\
\text { conditions for the functioning of } \\
\text { the ESCO formula in Poland from } \\
\text { three different perspectives. }\end{array}$ \\
\hline $\begin{array}{l}2 . \\
\text { CAWI } \\
\text { survey }\end{array}$ & $\begin{array}{l}\text { - } \quad 37 \text { local government units } \\
\text { - } \quad 16 \text { enterprises }\end{array}$ & $\begin{array}{l}\text { Expanding knowledge about the } \\
\text { ESCO formula in accordance with } \\
\text { the research questions }\end{array}$ \\
\hline $\begin{array}{l}3 . \\
\text { Focus } \\
\text { group } \\
\text { interview }\end{array}$ & $\begin{array}{ll}\text { - } & 2 \text { institutions that provide financial } \\
\text { support for energy industry projects } \\
\text { - } \quad 2 \text { local government units } \\
\text { - } \quad 2 \text { enterprises }\end{array}$ & $\begin{array}{l}\text { Analysing the survey results and } \\
\text { defining key findings, conclusions } \\
\text { and recommendations }\end{array}$ \\
\hline $\begin{array}{l}4 . \\
\text { Expert } \\
\text { panel }\end{array}$ & $\begin{array}{l}3 \text { representatives from academia and } 3 \\
\text { business representatives with } \\
\text { knowledge of how the ESCO } \\
\text { refundable financing formula works }\end{array}$ & $\begin{array}{l}\text { Additional independent } \\
\text { assessment of the conclusions and } \\
\text { recommendations formulated }\end{array}$ \\
\hline
\end{tabular}

It should be highlighted that the above research approach was chosen in agreement with the Polish Ministry of Energy [24] that commissioned and funded the research. The research was undertaken for the purpose of a general diagnosis of the factors influencing the interest of Polish entities towards implementing energy projects using the ESCO formula, as well as the identification of business models related to implementing energy projects using the ESCO formula in Poland. These are the reasons that the authors based their research on qualitative research instead of quantitative research. Qualitative research was more efficient thanks to its methodological approach, and provided sufficient results much faster than quantitative research. Additionally, using one of the foresight methods enriched the study and provided objective results, verified not only from the perspective of the target groups but also taking the feasibility of the recommended solutions into account, which were assessed by experts.

\section{Results}

4.1. Factors Influencing the Interest of Local Government Units and Enterprises in the Implementation of Energy Projects Using the ESCO Formula in Poland

In-depth interviews revealed that the ESCO formula is potentially interesting, especially for those entities which do not have many other possibilities to develop energy industry projects due to reasons such as the limited amount of European funds available, the demand for innovative financial solutions and the need to be supported in energy industry projects by professional consultancies. Local government units and enterprises are interested in ESCO services either as an alternative to grants and loans or in linking such sources of financing for energy projects, but so far, this mechanism has not been sufficiently researched by the respondents.

An analysis of the reasons for interest in the ESCO formula presented in Table 2 concludes that the target groups of the ESCO formula are eager to learn more about this mechanism when they have access to the appropriate information $(44.44 \%)$, when there are favourable economic conditions for projects based on the ESCO formula $(13.89 \%)$ and when they receive offers from ESCO companies and other entities (11.11\%). 
Table 2. Reasons for interest in the ESCO formula. Source: CAWI survey.

\begin{tabular}{crc}
\hline No. & Response Option & Responses (in \%) \\
\hline 1 & Available, approachable information about ESCO & 44.44 \\
2 & Possible savings on energy costs & 8.34 \\
3 & Results of previous successful projects & 2.78 \\
4 & Need to implement important projects & 5.55 \\
5 & Project evaluation conditions when applying for funding & 8.34 \\
6 & Investment tasks already underway & 2.78 \\
7 & Received offers for such activities & 11.11 \\
8 & Favourable economic conditions for projects based on the & 13.88 \\
9 & ESCO formula & 2.78 \\
10 & Other & 0.00 \\
\hline
\end{tabular}

The above findings were confirmed by the representatives of target groups that participated in the focus group interview. They stated that interest in the ESCO formula could not be linked with the innovative attitude towards new solutions supporting EE, but it results rather from access to reliable and objective but convincing information on this subject (e.g., campaigns conducted by public institutions) or from observing the positive effects of implementing the ESCO formula in other energy industry projects.

Concerning the sources of knowledge about the ESCO formula, the key conclusion coming from in-depth interviews was that the entities which can be potentially interested in implementing this mechanism are afraid whether the promises of ESCO companies and the conditions of implementation offered will be achievable in reality. The key reasons are not only the potentially improperly provided ESCO company services of but also the changing operating conditions of local governments units and enterprises (for example, changes in legal-administrative matters or to public aid rules). Considering the above-mentioned concerns, as well as a very dynamic situation in the energy market, many entities highlight that they cannot rely on the most available sources of information concerning the ESCO formula, as they may be out of date. One can say that the knowledge of the ESCO formula is quite superficial as evidenced by the respondents' identification of the Internet as a significant source of knowledge on the subject. Obviously, the Internet can be a source of information concerning the ESCO formula in the initial stage; however, the energy industry projects based on those mechanisms are very difficult and complex. They require interdisciplinary knowledge and experience, which cannot be provided based mainly on the Internet.

Table 3 shows that the largest number of respondents stated they were interested in the ESCO formula because of participation in the projects co-financed by European funds $(36.01 \%)$ or participation in commercial projects. It should be stated that participation in the projects does not mean that the respondents have a positive approach to the ESCO formula. Their opinion is based on the individual experience arising from particular projects. Another very popular source of interest is the Internet (22.23\%) as well as conferences and events $(13.88 \%)$. These sources of information are not equal in terms of information quality. Conferences and events have a very limited range, although they can deliver professional knowledge. The Internet provides more general information, whereas experiences related to participation in the project are much more concrete, although they can be either positive or negative.

The focus group interview confirmed that the Internet should be taken into account as a primary source of information when planning information campaigns about ESCO companies targeted at potential investors, including local governments units (e.g., owners of public buildings) and enterprises. The focus group interview participants showed that a highly specialised topic such as the ESCO formula could not be effectively explained based on general information and data because its effectiveness must be related to the specific scope of investment in each case. If an entity, when calculating the effectiveness of the ESCO formula, relies on information from the Internet rather than professional advice, mistakes 
or misinterpretation of the results are possible. The focus group interview participants, therefore, strongly advocated encouraging local governments units and enterprises to seek expert advice from ESCO companies. One also pointed out that the low interest in the ESCO formula results mainly from the lack of recognition of this instrument among potential users and a lack of knowledge about it.

Table 3. Sources of knowledge about ESCO formula. Source: CAWI survey.

\begin{tabular}{ccc}
\hline No. & Response Option & Responses (in \%) \\
\hline 1 & Participation in the EU projects & 36.01 \\
2 & Participation in the commercial projects & 8.34 \\
3 & Internet & 22.23 \\
4 & Training & 2.78 \\
5 & Information publications & 5.55 \\
6 & Scientific articles & 2.78 \\
7 & Participation in conferences and events & 13.88 \\
8 & Do not remember & 8.34 \\
& No opinion & 0.00 \\
\hline
\end{tabular}

Regarding the activities to increase the interest in the ESCO formula, the ESCO companies interviewed strongly emphasised the need to involve government institutions in popularising this mechanism in order to increase its credibility and objectively and reliably present it to potential investors, while information about the ESCO formula by companies providing such services is perceived as marketing activity rather than as reliable information.

The CAWI survey found (Table 4) that two important actions to increase interest in the ESCO formula are to improve access to knowledge about it (30.95\%) and to include it in grant projects $(26.19 \%)$. Both should be subordinated to the key action of improving access to expertise and objective information about this financing model. As many respondents $(21.42 \%)$ pointed out, much-needed action should be focused on the promotion and recognition of the ESCO formula. This also results from the fact that the financial engineering of an investment project based on a subsidy in connection with the ESCO formula may, in individual situations, raise doubts concerning the due amount of the subsidy and the eligibility of all costs or other conditions of using the subsidy, while the investor is unable to clarify these doubts. This may be the case particularly for companies preferring non-refundable financing, with much higher requirements for obtaining the grant compared to refundable financing. In these situations, a lack of expertise in the principles of the ESCO formula may discourage its use.

Table 4. Activities to increase interest in ESCO projects. Source: CAWI survey.

\begin{tabular}{ccc}
\hline No. & Response Option & Reponses (in \%) \\
\hline 1 & Improving the competitiveness of the ESCO formula against & 7.16 \\
2 & other forms of financing & 30.95 \\
3 & Improving access to knowledge about the ESCO formula & 26.19 \\
4 & Integrating ESCO into grant projects & 14.28 \\
5 & Regulatory changes & 21.42 \\
6 & Increased promotion and recognition of the ESCO formula & 0.00 \\
\hline
\end{tabular}

The interviewees pointed out the important issue of an objective presentation of the advantages and disadvantages of using the ESCO formula in energy industry projects because promoting this solution without pointing out the significant limitations and risks will not help increase credibility among local governments and enterprises in the long run. Reliable information regarding the ESCO formula should serve well to popularise it in various sectors of the energy market. 
During the focus group interviews, it was clearly stated that the activities related to increasing the interest in ESCO projects are strongly linked with the process of mitigating the barriers which restrain such investments in the energy industry. There are many more obstacles than incentives for local government units, as well as the enterprises which would like to implement the ESCO formula in their projects. That is why it is necessary to indicate and analyse the key barriers of ESCO formula implementation in public and commercial projects related to the energy industry.

In the question regarding the factors reducing the interest of local governments and enterprises in investing in the ESCO formula, a rather diverse set of answers was obtained (Table 5). A significant percentage of respondents said that savings possible under the ESCO formula were not enough to tempt them into using the model in the first place $(45.23 \%)$. Other factors cited by a relatively large percentage of respondents (lack of regulation-21.42\% or insufficient legal regulations-26.19\% as well as the issue of debt increase-23.80\%) once again confirm that those potentially interested in the ESCO formula are not familiar with the details of its principles of operation.

Table 5. Factors reducing interest in ESCO investments. Source: CAWI survey (multiple choice questions).

\begin{tabular}{ccc}
\hline No. & Response Option & Reponses (in \%) \\
\hline 1 & Complicated decision-making and ownership processes & 11.90 \\
2 & Competition from grants & 19.04 \\
3 & Competition from banks & 4.76 \\
4 & Lack of adequate consulting & 14.28 \\
5 & Underestimation of savings relate to the ESCO formulation & 45.23 \\
6 & Increase in local government debt or corporate debt & 23.80 \\
7 & Lack of familiarity with the ESCO formula & 21.42 \\
8 & Insufficient legal regulations & 26.19 \\
9 & Other & 4.76 \\
10 & No opinion & 0.00 \\
\hline
\end{tabular}

Knowledge regarding the barriers that local governments and enterprises identify in relation to the ESCO formula was expanded through the focus group interview and in-depth interviews. The feedback collected from respondents indicates that:

- the best method of encouraging local governments units and enterprises to use the ESCO formula may be the presentation of examples of such investments in different variants and the resulting benefits - the focus should be on pilot investments using public funds in places where market solutions are not viable due to numerous risks;

- insufficient or unclear legal regulations regarding the ESCO formula are mainly related to the fear of receiving state aid, which discourages the use of this mechanism;

- inconsistent interpretations as to how ESCO-related liabilities should be recognised in the financial statements of local governments units and enterprises meaning that for many entities already carrying high debt rates, this solution cannot be taken into account;

- complicated decision-making and ownership processes regarding the ESCO formula relating primarily to the problems of determining the ownership of the components of the ESCO installation, the adoption of uniform rules for the accounting and depreciation of fixed assets and the recognition of expenses incurred and savings generated in the financial statements, further multiply the legal doubts regarding the proper inclusion of such operations in the accounting ledgers.

\subsection{Solutions Supporting the Implementation of the ESCO Formula in Poland}

The study found that despite many barriers limiting interest in the ESCO formula, local governments units and enterprises are generally eager to implement particular types of ESCO services in combination with various financial supports. The in-depth interviews revealed that a general problem of projects co-financed with grants or loans is the lack of comprehensive consulting services available throughout the project life-cycle. Such services 
are necessary in order to choose the optimal path of energy industry project implementation and to take all required standards and requirements into account. Meanwhile, local government units and enterprises often lack the expertise to independently design solutions best suited to their particular conditions and needs. They focus on those activities that are, for instance, eligible for co-financing as part of a grant, omitting those that cannot be considered eligible.

Financial support, without additional activities of a formal and informative nature, may lead to inefficient use of the funds, as exemplified by energy efficiency investments in public buildings implemented under the green investment scheme audited by the Polish Supreme Audit Office [42]. Therefore, it is crucial to correctly identify the solutions which can be possible and most beneficial to implement energy projects using the ESCO formula in Poland.

The results of the in-depth interviews were confirmed by the CAWI survey (Table 6). The majority of respondents want expert consulting (61.90\%) and energy audits (52.38\%), that are necessary to determine the scope and method of implementation of an energy industry project. The high demand for technical services in the project $(45.23 \%)$ once again confirms the lack of competence of local government units and enterprises to handle this type of investment on their own. This is an important factor to consider when taking steps to popularise the ESCO formula. As one interviewee stated during an in-depth interview, "the financing entity does not really need an energy audit; it is in the interest of the investor".

Table 6. Services offered in the ESCO formula. Source: CAWI survey (multiple choice questions).

\begin{tabular}{ccc}
\hline No. & Response Option & Reponses (in \%) \\
\hline 1 & Energy retrofits of buildings-securing financing & 23.80 \\
2 & Heat source replacement-securing financing & 30.95 \\
3 & Expert consulting & 61.90 \\
4 & Conducting an energy audit & 52.38 \\
5 & Technical support for the project at the planning and & 45.23 \\
& implementation stage & 23.80 \\
6 & Handling the subsidy program for inhabitants (energy & 4.76 \\
7 & retrofit, heat source replacement, RES installation) & 0.00 \\
\hline
\end{tabular}

The focus group interview participants noted that utilising the wide range of services of the ESCO formula increases the chance that an energy industry project will achieve the expected savings. In their view, the framework scope of ESCO services in an energy project should include:

- conducting an energy audit and multi-criteria economic and technical analysis of the profitability of the implementation of the project in various business models,

- technical and economic consulting on choosing the optimal variant of project implementation,

- ensuring financial engineering for the project,

- participation in the design of technical solutions and appropriate selection of equipment,

- participation in investment project management and accounting settlement,

- $\quad$ participation in energy management after project completion, and

- maintenance and operation of equipment acquired as part of the project.

According to in-depth interviews results, the solutions related to investing in energy industry projects that involve the use of the ESCO formula should consider two equally important elements:

- $\quad$ the benefits expected by investors: local government units and enterprises implementing such projects, and

- $\quad$ sustainable public strategies of the local government units and sustainable business strategies of enterprises and ESCO companies. 
Additionally, the participants of the in-depth interviews noted that ultimately, a move away from direct grant funding to a mixed mechanism, i.e., grants with forgiveness, should be recommended.

The local government units and enterprises surveyed evaluated the attractiveness of various financing instruments for energy projects in different ways (Table 7). Obviously, the most popular are European funds (33.33\%), but it should be stated clearly that it is probable that this source of capital will be limited gradually in the next European financial perspectives of the cohesion policy. Traditionally, loans, either long-term and returnable $(21.42 \%)$ or forgivable $(7.14 \%)$ are also popular. It is very puzzling that as many as one-fifth of the respondents have no opinion at all.

Table 7. Interest in types of ESCO services. Source: CAWI survey (multiple choice questions).

\begin{tabular}{ccc}
\hline No. & Response Option & Responses (in \%) \\
\hline 1 & EU grant & 33.33 \\
2 & National grant & 4.76 \\
3 & Long-term loan & 21.42 \\
4 & Forgivable loan & 7.14 \\
5 & Public-private partnership & 2.38 \\
6 & Other & 9.52 \\
7 & No opinion & 21.45 \\
\hline
\end{tabular}

The CAWI survey confirmed that respondents are unable to identify the solutions that work best in conjunction with the ESCO formula. Opinions on this topic are very divided. Below is the distribution of responses to the question as to what types of projects the respondents would want to associate with the ESCO formula:

- $\quad$ projects with repayable funding (7.14\% of respondents),

- $\quad$ projects with non-repayable funding (7.14\% of respondents),

- $\quad$ projects with public-private partnerships (4.76\% of respondents).

A total of $80.96 \%$ of the respondents had no opinion on this issue. It confirms again that the key challenge to increasing the number of energy industry projects based on the ESCO formula is to educate target groups in terms of its usefulness. Otherwise, they are not aware of what projects can be the implemented using the ESCO formula and what financial models can be applied with such a formula.

The assessment of ESCO formula value for the potential investors should consider identifying the potential benefits expected by those who use or intend to use ESCO services. The respondents in the CAWI survey identified the following benefits:

- $\quad$ savings in energy consumption (80.95\% of respondents);

- modernisation of existing infrastructure (52.38\% of respondents);

- $\quad$ energy efficiency improvement consulting (28.57\% of respondents);

- $\quad$ environmental benefits (7.14\% of respondents).

Energy savings that translate into financial savings are a key benefit of the ESCO formula for the vast majority of respondents $(80.95 \%)$. At the same time, such factors as the scope of investment and its potential connection with public aid (e.g., energy retrofitting, the replacement of lighting systems, the purchase of electric busses) and the type of entity implementing the investment (local government, enterprise) are factors which objectively condition the different scope of benefits possible to obtain from the energy project. It is lamentable that environmental benefits are important for only $7.14 \%$ of respondents, which indicates that sustainable public and business strategies are not core policies for the potential beneficiaries of the ESCO formula.

ESCO companies shape their offerings in relation to the expectations of different target groups in the energy market while being guided by criteria such as profitability or potential market size for a given service. The results of the in-depth interviews indicate that the current dominant investor groups in the ESCO services market are: 
- local governments at all levels, and

- large-scale industrial plants where energy demand is the highest. Slightly less popular among energy service companies are:

- $\quad$ other public entities such as universities, hospitals, etc., and

- housing associations and cooperatives.

Due to the dispersed structure of this market, it is currently difficult to quantify its size.

The CAWI survey identified the likeliest prospective target groups for ESCO services as:

- $\quad$ the industrial sector $(23.08 \%$ of respondents),

- local governments ( $15.38 \%$ of respondents),

- office buildings and shopping centres ( $15.38 \%$ of respondents), and

- $\quad$ small and medium-sized enterprises (7.69\% of respondents).

The in-depth interviews resulted in the formulation of key characteristics that encourage investment projects to use the ESCO formula:

1. high profitability (benefits are distributed between the investor and the ESCO)

2. the implementation of the project in an industry where a high EE of investment can be obtained

3. adequate liquidity and securing of funds by the ESCO that are attractive for investors without their own contribution

4. the possibility for the investor to verify the level of competence of the ESCO and the quality of its offer

5. sufficient knowledge of $\mathrm{EE}$ issues by the investor

The focus group identified the leading types of energy industry projects that are feasible under the ESCO formula while providing the potential for satisfactory savings. At the same time, they indicated the potential current and future target groups of the ESCO formula in Poland (sectors and branches). One agreed that these are projects related to:

- improving the energy efficiency of buildings and their surroundings (e.g., lighting),

- modernisation of heat sources and heating networks,

- projects implemented to reduce the energy intensity of processes or industrial infrastructure modifications.

Lighting replacement and industrial projects were found to be the most financially viable. On the other hand, investments in the energy retrofitting of public utility and residential buildings, including the so-called deep energy retrofits, are characterised by a longer payback period, which is not always acceptable for the investor. The ESCO formula is particularly suitable for projects that combine energy retrofits with other investment activities, such as energy source replacement. As the interviews show, the role of ESCO is also important in the context of construction. This is true not only in industry, where financial efficiency is higher but also in local government construction projects, where procedures for energy efficiency improvement, e.g., standards for energy audits, have already developed. Energy audits are much more expensive in industry as they have to be more extensive and are often carried out on the basis of measurements, as they are the basis for the formulation of contracts and future settlements between the energy service company and the investor. The technological complexity, but also the need to monitor the effects, substantially justify the involvement of qualified entities such as ESCO companies.

\section{Discussion}

Although ESCO in Poland is not a new form of accounting for investments aimed at improving energy efficiency, many entities still do not have sufficient knowledge about it, which was clearly confirmed by the results of the survey. The process of accounting for investments in the ESCO mechanism is perceived as time-consuming and complicated, and above all, has been researched to a much lower degree than, for example, the procedures of using EU funding. These factors and other conditions highlighted in the study demonstrate that the ESCO market, although in existence for nearly 30 years, is still in its early stages of development [3]. The result of our research was in line with the expected results [9]. Often 
this lack of knowledge means that local governments or enterprises expect deep energy retrofits to be absolutely necessary for ESCO projects and find it difficult to understand that even small, local investment projects combined with optimisation of energy management processes can significantly improve energy efficiency and thus lead to lower monthly energy costs. Meanwhile, research confirms that the benefits of energy savings and reduced energy costs are the key criteria for investors to become interested in the ESCO mechanism. The statement agrees with Trianinin et al. [13], which shows that an economic driver is crucial for companies regardless of their size.

Potential investors using the ESCO mechanism, i.e., local governments and enterprises, have an only superficial knowledge of the working principles of this mechanism. Because research has shown that in many cases, interest in this topic only arises in connection with incoming offers from ESCO companies, the common belief in this topic is that it involves incurring expenses for various types of consulting services and thus having to accept the risk of investment failure. Few entities are aware that in the ESCO mechanism, increasing energy efficiency does not have to involve capital expenditure.

Polish local government units and enterprises have become accustomed to using grant or loan formulas, so the solution of placing the burden of financing an energy project on an ESCO company is still quite innovative and even arouses incredulity. Other innovative financing models, such as energy cooperatives or crowdfunding, however common in other countries [25,26], are not known in the Polish public sector. They are the domain of activities, such as technology start-ups, also in the energy sector. The public sector remains conservative. The fact, proved by the research, that knowledge on the subject is mainly drawn from the Internet and not from professional advisors is not conducive to a proper understanding of the ESCO financing mechanism. For many investors, the method of financing energy investments by an ESCO coupled with its commitment to achieving a certain level of savings from energy utility expenses raises many questions. Innovative elements appearing in this model (e.g., an escrow account, used for settlements with the ESCO) or ambiguities (e.g., the necessity of appropriate recognition in financial statements of costs and revenues from the ESCO mechanism) also negatively influence interest in this form of financing energy investments.

Reliable and comprehensive information and promotion activities conducted by public institutions should, therefore, be considered crucial. They should serve to present the ESCO mechanism in an objective manner, considering its advantages and limitations. Above all, however, they should serve to educate investors in energy projects about energy efficiency itself and the possibilities of improving it using the ESCO mechanism. When such knowledge is missing, the simplest solutions are resorted to (e.g., grants or loans), which are also burdened with disadvantages or at least result in various types of limitations.

According to the research, the task of popularising the ESCO mechanism should fall to both the entities responsible for the national energy policy, as well as ESCO companies themselves. Barriers to the use of ESCO in Poland were identified and diagnosed several years ago, and specific recommendations were formulated. The report by the World Bank and Ministry of Development [20] also pointed out the need to develop model templates and documents, introduce changes in the budgeting rules for the procurement system to enable EPC contracts, establish nodal energy agencies and recruitment of project facilitators, launch incentive mechanisms and financing schemes, develop of targets for energy efficiency indicators for public offices and prepare measurement and verification reports, etc. This can contribute firstly to the process being promoted and popularised at all times, secondly to the gains in energy efficiency being sustained, and thirdly to measures being put in place to realise more significant potential energy savings [20]. Our research supplemented the results with the needs resulting from the specificity of EU funds and changes in the conditions in the 2021-2027 period.

It is difficult to pinpoint why, despite recognising this problem, not enough has been done to improve the promotion of ESCO companies in the energy market. ESCO companies competing for customers have found it challenging to demonstrate the attractiveness and 
competitiveness of this formula against, for example, grants. In the case of grants, many public and local government institutions had high budgets for information and promotional activities to attract applicants and beneficiaries and ultimately demonstrate the achievement of indicators in EU programs. As a result, respective resources were used to promote grant programs, but ESCO was not mentioned in energy projects.

In light of the research, however, it appears that the most work remains to be done in the legislative area. The legal barriers are identified by Bertoldi and Boza-Kiss [9] and Trianni, Cagno and Farné [13], and we agree with the authors cited in this regard. This concerns primarily unambiguous jurisprudence and implementation of uniform formal and legal solutions facilitating the use of ESCO both by public sector entities and commercial entities, by both housing associations, and cooperatives. Insufficient or unclear legal regulations regarding the ESCO mechanism are primarily related to the fear of receiving state aid, which is consistent with Rogić Lugarić, Dodig and Bogovac [7]. Exceeding public aid limits may mean the necessity of returning the resources with statutory interest. There is also insufficient interpretation on how to record liabilities from using the ESCO mechanism in local governments and enterprises (especially the impact of ESCO on local government debt rates. Great interpretive difficulties also pertain to accounting for savings from the ESCO mechanism. In the latter regard, it is worth citing the examples of Germany and the United States, where, in order not to exceed debt ceilings, contractual EPC payments qualify as an operating expense. In some countries, EPC contracts are included in calculating the debt ceiling of public sector entities. In contrast, in Germany and the US, for example, EPC contracts are permitted provided the following criteria are met:

- the ESCO must incur commercial debt and account for it on its balance sheet, and

- the project has a guaranteed positive cash flow to the government agency every year of the contract, backed by rigorous performance guarantees, including performance and payment bonds, certificates of insurance or surety bonds.

As long as the above conditions are met, payments to the EPC contractor are counted as operating expenses (building maintenance) and not as debt repayment [30].

The above proves that for the formula to grow on the Polish market, it is crucial to clearly define whether repayments to ESCO should be reported as debt or included in operating expenses [20]. Such solutions have been introduced in Poland in the amended Act on energy efficiency, where a provision has been added: obligations resulting from an energy efficiency improvement contract do not affect the level of public debt and the deficit of the public finance sector, where the energy services provider bears most of the construction risk and the risk of achieving a guaranteed level of average annual energy savings, taking into account the impact on these risks of factors, such as guarantees and financing by the energy services provider as well as asset allocation at the end of the contract. However, while clarifying much, this provision still does not entirely convince potential investors from the public sector to use ESCO.

Although many barriers indicated by the studies (e.g., competition from grants, the too-small scale of savings from ESCO) cannot be fully eliminated, this formula can be successfully improved, e.g., by combining it in certain variants of financial engineering with grants and forgivable loans or by transferring more innovative and effective technological solutions to the Polish market, allowing for the generation of greater savings from the use of the ESCO mechanism.

It is also worth emphasising the important role played by companies providing such services in popularising the ESCO mechanism. The research clearly showed that the elements of ESCO service that are essential in proper project planning are expert advice and professional performance of energy audits. Unfortunately, practice shows that in many projects, this element is omitted or implemented incorrectly, as a result of which even correct implementation of the investment does not guarantee obtaining the expected improvement in energy efficiency. ESCO companies should therefore do much more to advise and even educate their customers on the importance of the planning process for the final results of an energy project. 
ESCO companies recognise the potential of this market and are able to identify target groups with whom they would like to carry out energy projects now, and in the future, but the principles of the functioning of this market depend on many conditions, including many which are completely independent from this market. One such factor is the international and domestic energy policy, which has a large impact on the viability of the ESCO business model. The current form of documents, such as the European Green Deal [54], NextGenerationEU (European Instrument for Reconstruction and Increasing Resilience) [55] and EU Cohesion Policy 2021-2027 (European Cohesion Policy 2021-2027) [56] indicate a very large proportion of energy projects in financing the development processes of the European Union in the coming years. This opens a number of new possibilities for the use of the ESCO mechanism and is an important argument for its further improvement. In this aspect, the current level of interest in particular types of ESCO services which emerges from the research may increase significantly in the coming years, which opens new prospects for this market.

We should also not forget the growing awareness of institutional and individual customers about the impact of industrial production and other human activities on climate change. It is to be expected that consumers will increasingly attach more importance to the way in which a product or service is produced or provided, and more specifically, will be interested in ensuring that this process takes place in the most sustainable manner possible, with the least possible damage to humans and the environment. Therefore, many entities will seek to intensify energy efficiency measures for their operations in a way that does not increase costs and maintains the existing competitiveness of their products and services.

When referring to the business models that can be applied to the ESCO mechanism, it is hard to ignore the fact that they generate risks primarily for the energy service company itself. Such a company may rely on its own or returnable capital, e.g., on repayable financing in the form of a preferential loan fund granted to it by state institutions. The company, in turn, organises an open call for proposals for ESCO projects within a specific technical and technological framework. In order for the whole project to be successful, it is necessary to introduce an appropriate formal and legal framework and for public institutions to run educational campaigns aimed at encouraging both entities (ESCO and investors) to implement the ESCO mechanism. An important element facilitating the functioning of this mechanism may be, for example, an escrow account, which serves as collateral for the repayment of the liabilities of the investor towards the ESCO. It should be emphasised that it is the energy service company that bears the entire risk of not achieving energy savings and return of funds from the loan fund to state institutions, which must be factored in its business activity and included in the contract.

The way in which the parameters of each project are approached depends primarily on its scale, size and potential environmental and financial effects. Therefore, a case-bycase approach is recommended for selecting the parameters of a specific ESCO contract. Research-based criteria for evaluating target groups should also be part of the contract. The key criterion is the profitability of the contract with the entity, which should be correlated with the level of risk the ESCO is willing to bear. Other important elements of the contract include the contribution of the investor, the interest rate on the preferential loan, the payback period, the preparation fee, and how the cost savings will be distributed in correlation with the planned payback period.

The main benefit of using the ESCO mechanism is the reduction of the need for the investor to make a contribution and the quick benefits from the savings on energy costs, which appear immediately after the completion of the investment and start of operation which is in line with the European Energy Service Initiative [34].

The application of the ESCO mechanism usually binds the owner of the facility to the ESCO for many years in terms of defining the effects (e.g., by means of an EPC contract), and during the operation-monitoring the effects, which are the basis for accounting settlements. This approach reduces mismanagement on the one hand but at the same time requires patience on both sides when it comes to the rate of return on investment. Taking into 
consideration the results of the audit of energy efficiency investments made in public-use organisations by the Polish Supreme Audit Office [42], the results of our research confirm the need for and gaps in specialist knowledge and ineffective investment implementation mechanisms. Major shortcomings were also identified at the initial stage of defining design assumptions and later at the stage of monitoring energy effects during operation. The popularisation of investments within the ESCO mechanism should be accompanied by procedures and formal documentation at each stage of investment (planning, tender, implementation, monitoring and settlement) so that it is not possible to repeat the mistakes indicated in the cited audit report.

\section{Conclusions}

The research problem of the study was to identify the determinants of the use of the ESCO mechanism by local government units and enterprises implementing energy projects. The research conducted by the authors, which was also addressed to the Polish Ministry of Energy, provided a number of interesting observations and conclusions which enabled achieving the research objectives defined in the paper.

The first objective of the study was to determine the factors affecting the interest of Polish local government units and enterprises in implementing energy projects in the ESCO mechanism. The research revealed that the lack of knowledge of local government units and enterprises regarding the ESCO mechanism, although not unique to Poland, is not a sufficient explanation for the low interest in this solution. The problem is much more complex, and its sources should be sought first in the poor preparation of Polish local governments and enterprises for the energy transition, and second in the legislative and interpretational ambiguities that have grown around the ESCO mechanism. Theoretically, investors implementing energy projects should have full knowledge of the conditions and consequences of implementing these projects in different business models (e.g., grant, forgivable loan, credit, ESCO), but in practice, they often choose the simplest, most accessible or highly advertised solutions. For this reason, interest in grants, for example, far exceeds interest in the ESCO mechanism. In the case of EU funds, for example, the rules for project implementation and criteria for the eligibility of costs, as well as conditions for project accounting settlement and maintenance of its sustainability, are clearly and comprehensively defined, and access to advice on EU grants is widespread. The rules of accounting for investments in the ESCO mechanism are much more complex and individualised, depending on multiple factors. When a local government or an enterprise is poorly informed regarding the technological solutions in the area of improving investment efficiency, the simplest solutions, generating the least risk, are usually selected. Thus, the first key conclusion to be drawn from this article is the need to educate local governments and enterprises in the field of energy efficiency, which is key to interesting them in the more complex ESCO implementation models. Such educational tasks should be primarily the responsibility of public institutions shaping the national energy policy, but also of the ESCOs themselves. The research confirmed that energy service companies pay particular attention to educating investors and offer them expert consulting during the planning and implementation stages of the project, but this is not always understood by local governments and enterprises. With regard to the results of the research, another important conclusion can be drawn - that the information addressed to investors to increase their knowledge regarding the ESCO mechanism should be formulated in terms of benefits and should be based on various examples of ESCO mechanism applications in investment projects by local governments and enterprises. While the Internet should remain the first source of information on ESCO for investors, the availability of expert consulting should be improved, and investors should be encouraged to commission professional energy audits as a first step in the planning process for energy projects. Meanwhile, investors often want to save on consulting and audits, not being aware that by following this path they lose the opportunity for a reliable analysis of different options for project implementation. 
Expert consulting by ESCOs is also essential to provide investors with reliable and credible information on the terms and conditions of ESCO projects. As the research has shown, there are many stereotypical associations about the ESCO mechanism (e.g., the need to combine ESCO with a deep energy retrofit) or innovative elements that are not yet trusted by investors (e.g., the method of settlement with the energy service company through an escrow account). The ESCO mechanism connected with a grant also often raises questions from the perspective of state aid regulations, which are quite unclear. It seems that in spite of existing research and previously formulated recommendations, which are also referred to by the authors of this paper, solutions have still not been implemented to reduce barriers to the use of the ESCO mechanism, e.g., the development of model document specimens for conducting and accounting for EPC contracts, the establishment of nodal energy agencies, as well as the introduction of ESCO incentive mechanisms and financing schemes.

This last element, concerning the provision of funding sources for umbrella programs for the energy service companies, is considered by the authors as especially crucial for the further development of this market. The second research objective formulated in this study, i.e., the identification of business models in which it is possible to implement energy projects in the ESCO model in Poland, was highly related to determining:

- What mechanisms do ESCOs and investors want to implement in such contracts?

- Which target groups and types of projects are strategic in terms of marketing for the ESCOs?

By following the project implementation process in the ESCO mechanism, we can conclude that it generates risk primarily for the energy service company itself. For this reason, it is doubtful that energy service companies will invest the equity necessary to develop this challenging market. An ESCO generally relies on repayable capital from a preferential loan fund operated by state institutions. Since research has shown that the growth of the ESCO market is derived from the availability of public funds for the ESCOs servicing the contracts, a third important conclusion concerns the need for the state to provide adequate capital to such companies. The task of the energy service company is to effectively carry out the call for projects to be implemented in the ESCO mechanism and to service them in terms of finances, organisation and technology. It is in the interest of the state to create a competitive ESCO market that creates broad access to operators for the investors. However, it should be clearly emphasised that given the current perception of the novelty of the ESCO mechanism in the Polish energy market, the effective development of this market is possible only with the intensification of educational activities by state institutions and the professionalisation of the activities of ESCO companies. The amendment of the Act on energy efficiency and the activity of the Ministry of Climate to promote the ESCO mechanism should be evaluated positively.

According to the research, the new perspective for EU funds 2021-2027 will continue to allow local governments and enterprises to access grants for energy efficiency improvements, but in many cases, the conditions for obtaining grants may not meet all investor expectations. This results in an even greater necessity to promote hybrid financial engineering for projects that can combine, for example, the ESCO mechanism with grants and forgivable loans. However, this requires investors to be provided with expert advice on the planning and implementation of such projects while also giving them access to modern technological solutions offering a longer lifespan and greater savings in energy consumption.

A final element worth emphasising is the growing public awareness of the impact of industrial production and other human activities on climate change. Improving energy efficiency in the activities of public institutions or enterprises is an important element of the social communication of these organisations with their stakeholders. Energy projects that generate returns for investors while helping to mitigate the effects of climate change and prevent further change are increasingly socially desirable, and this is yet another reason to promote the ESCO mechanism. 
These conclusions of the research conducted on behalf of the Polish Ministry of Energy have been reviewed by a panel of experts. The panel included representatives from academia and business with knowledge of how the ESCO refundable financing mechanism works. The problem of public debt and EPC contracts in the public sector identified in the research has also been confirmed, as evidenced by the cited amendment to the Act on energy efficiency, which clarifies the situations whereby EPC contracts will not increase the level of public debt. Nevertheless, the research presented in this article has some limitations due to its methodology. These limitations relate to the national nature of the research (which is why the title emphasises that the article concerns Poland). In addition, it is necessary to take the dynamic nature of the international and domestic energy market into account (green deal, COVID, development of prosumer installations), which results in equally dynamic changes in the preferences of investors and the conditions for ESCOs. It should also be emphasised that the research was commissioned by the then Ministry of Energy, and the research problems addressed were in response to the needs of the said ministry. Nevertheless, the identified research gap-the limited number of national academic publications addressing the topic of ESCO projects, remains timely and inspiring.

As further directions of research regarding the ESCO mechanism, the authors point to the assessment of the importance of the ESCO mechanism in the transformation of the energy sector, in particular, research on the perception of the mechanism from the perspective of stakeholders and the further development of business models related to the ESCO mechanism-for example, in the context of changes in the conditions for applying for EU funds in the 2021-2027 period.

Author Contributions: Conceptualisation, J.K.-P. and G.K.; methodology, J.K.-P. and G.K.; validation, J.K.-P. and G.K.; formal analysis, J.K.-P. and G.K.; investigation, J.K.-P. and G.K.; resources, J.K.-P. and G.K.; writing-original draft preparation; writing—review and editing J.K.-P. and G.K.; visualisation, J.K.-P. and G.K.; supervision, J.K.-P. and G.K. All authors have read and agreed to the published version of the manuscript.

Funding: The authors based on the research conducted by them as a part of the study commissioned and funded by the Polish Ministry of Energy. The study was co-financed by the Cohesion Fund. The APC costs of the article was financed by Warsaw University of Technology, the cost of language proofreading by the WSB University.

Institutional Review Board Statement: Not applicable.

Informed Consent Statement: Not applicable.

Conflicts of Interest: The authors declare no conflict of interest.

\section{References}

1. IEA. Energy Efficiency 2020; International Energy Agency: Paris, France, 2020.

2. Román-Collado, R.; Economidou, M. The Role of Energy Efficiency in Assessing the Progress towards the EU Energy Efficiency Targets of 2020: Evidence from the European Productive Sectors. Energy Policy 2021, 156, 112441. [CrossRef]

3. Boza-Kiss, B.; Bertoldi, P.; Economidou, M. Energy Service Companies in the EU: Status Review and Recommendations for Further Market Development with a Focus on Energy Performance Contracting; Publications Office of the European Union: Luxembourg, 2017; ISBN 9789279714757.

4. Patterson, M.G. What Is Energy Efficiency?: Concepts, Indicators and Methodological Issues. Energy Policy 1996, 24, 377-390. [CrossRef]

5. Bolton, R.; Hannon, M. Governing Sustainability Transitions through Business Model Innovation: Towards a Systems Understanding. Res. Policy 2016, 45, 1731-1742. [CrossRef]

6. Carbonara, N.; Pellegrino, R. Public-Private Partnerships for Energy Efficiency Projects: A Win-Win Model to Choose the Energy Performance Contracting Structure. J. Clean. Prod. 2018, 170, 1064-1075. [CrossRef]

7. Rogić Lugarić, T.; Dodig, D.; Bogovac, J. Effectiveness of Blending Alternative Procurement Models and EU Funding Mechanisms Based on Energy Efficiency Case Study Simulation. Energies 2019, 12, 1612. [CrossRef]

8. IEA. Energy Service Companies (ESCOs); International Energy Agency: Paris, France, 2018.

9. Bertoldi, P.; Boza-Kiss, B. Analysis of Barriers and Drivers for the Development of the ESCO Markets in Europe. Energy Policy 2017, 107, 345-355. [CrossRef] 
10. EC JRC, Energy Service Market in the EU: Status Review and Recommendations 2019; Publications Office of the European Union: Luxembourg, 2019; ISBN 978-927-613-093-2.

11. Ministry of Climate and Environment ESCO-Type Energy Services on the Polish Market-Open Data. Available online: https: / / dane.gov.pl/pl/dataset/1727, usugi-energetyczne-typu-esco-na-polskim-rynku (accessed on 21 July 2021). (In Polish)

12. ZWM. Detailed Description of the Priority Axes of the Regional Operational Program of the Mazowieckie Voivodeship for 2014-2020; Board of the Mazowieckie Voivodeship: Warsaw, Poland, 2017. (In Polish)

13. Trianni, A.; Cagno, E.; Farné, S. Barriers, Drivers and Decision-Making Process for Industrial Energy Efficiency: A Broad Study among Manufacturing Small and Medium-Sized Enterprises. Appl. Energy 2016, 162, 1537-1551. [CrossRef]

14. Okay, N.; Akman, U. Analysis of ESCO Activities Using Country Indicators. Renew. Sustain. Energy Rev. 2010, $14,2760-2771$. [CrossRef]

15. Hannon, M.J.; Bolton, R. UK Local Authority Engagement with the Energy Service Company (ESCo) Model: Key Characteristics, Benefits, Limitations and Considerations. Energy Policy 2015, 78, 198-212. [CrossRef]

16. Lu, Z.; Shao, S. Impacts of Government Subsidies on Pricing and Performance Level Choice in Energy Performance Contracting: A Two-Step Optimal Decision Model. Appl. Energy 2016, 184, 1176-1183. [CrossRef]

17. Garbuzova-Schlifter, M.; Madlener, R. AHP-Based Risk Analysis of Energy Performance Contracting Projects in Russia. Energy Policy 2016, 97, 559-581. [CrossRef]

18. Lee, P.; Lam, P.T.I.; Lee, W.L. Risks in Energy Performance Contracting (EPC) Projects. Energy Build. 2015, 92, 116-127. [CrossRef]

19. Pantaleo, A.; Candelise, C.; Bauen, A.; Shah, N. ESCO Business Models for Biomass Heating and CHP: Profitability of ESCO Operations in Italy and Key Factors Assessment. Renew. Sustain. Energy Rev. 2014, 30, 237-253. [CrossRef]

20. Vandycke, N. Poland-Ex-Ante Evaluation of Financial Instruments; For the Proposed "Infrastructure and Environment" Operational Program for 2014-2020 in Selected Sectors: Energy and Solid Waste; The World Bank and the Ministry of Regional Development: 2013. Available online: https:/ / www.gov.pl/attachement/16c5a9af-519e-4855-835f-e2d163bd9597 (accessed on 1 December 2021).

21. Lisowski, R.; Woźniak, M.; Jastrzębski, P.; Karafolas, S.; Matejun, M. Determinants of Investments in Energy Sector in Poland. Energies 2021, 14, 4526. [CrossRef]

22. Rajek, Ł.; Liszka, S.; Rajek, Ł. Overview of the EPC Potential and Market. National Report for Poland WP3 Combines Project Central Europe Programme/4CE499P3; Polish Foundation for Energy Efficiency: Katowice, Poland, 2013.

23. Bogdan, R.; Biklen, S.K. Qualitative Research for Education an Introduction to Theory and Methods; Pearson: Boston, MA, USA, 2009; ISBN 9780205512256.

24. Kreatus Ltd. Opportunities for the Implementation of the ESCO Mechanism under Priority Axis I of the Infrastructure and Environment Operational Programme 2014-2020; Kreatus Ltd: Bielsko-Biała, Poland, 2018. (In Polish)

25. Yildiz, Ö.; Rommel, J.; Debor, S.; Holstenkamp, L.; Mey, F.; Müller, J.R.; Radtke, J.; Rognli, J. Renewable Energy Cooperatives as Gatekeepers or Facilitators? Recent Developments in Germany and a Multidisciplinary Research Agenda. Energy Res. Soc. Sci. 2015, 6, 59-73. [CrossRef]

26. Ari, I.; Koc, M. Philanthropic-Crowdfunding-Partnership: A Proof-of-Concept Study for Sustainable Financing in Low-Carbon Energy Transitions. Energy 2021, 222, 119925. [CrossRef]

27. Polzin, F.; von Flotow, P.; Nolden, C. What Encourages Local Authorities to Engage with Energy Performance Contracting for Retrofitting? Evidence from German Municipalities. Energy Policy 2016, 94, 317-330. [CrossRef]

28. Brown, D. Business Models for Residential Retrofit in the UK: A Critical Assessment of Five Key Archetypes. Energy Effic. 2018, 11, 1497-1517. [CrossRef]

29. Streimikiene, D.; Balezentis, T. Willingness to Pay for Renovation of Multi-Flat Buildings and to Share the Costs of Renovation. Energies 2020, 13, 2721. [CrossRef]

30. Langlois, P.; Hansen, S.J. World ESCO Outlook; Fairmont Press: Lilburn, GA, USA, 2012; ISBN 9781466558144.

31. 2012/27/EU Directive 2012/27/EU of the European Parliament and of the Council of 25 October 2012 on Energy Efficiency, Amending Directives 2009/125/EC and 2010/30/EU and Repealing Directives 2004/8/EC and 2006/32/EC Text with EEA Relevance 2012. Off. J. Eur. Union L.315/1 2012, 4, 204-257.

32. Akman, U.; Okay, E.; Okay, N. Current Snapshot of the Turkish ESCO Market. Energy Policy 2013, 60, 106-115. [CrossRef]

33. Hannon, M.J.; Foxon, T.J.; Gale, W.F. The Co-Evolutionary Relationship between Energy Service Companies and the UK Energy System: Implications for a Low-Carbon Transition. Energy Policy 2013, 61, 1031-1045. [CrossRef]

34. Graz Energy Agency; Berlin Energy Agency. Facilitators Guideline for Energy Performance Contracting. European Energy Service Initiative-EESI2020. 2014. Available online: https://guaranteeforum.eu/file/download/4286735d-af19-4397-89af-45aadb555 e5d/1593786338eesi2020_epc_facilitators_guideline.pdf (accessed on 1 December 2021).

35. Soroye, K.L.; Nilsson, L.J. Building a Business to Close the Efficiency Gap: The Swedish ESCO Experience. Energy Effic. 2010, 3 , 237-256. [CrossRef]

36. Suhonen, N.; Okkonen, L. The Energy Services Company (ESCo) as Business Model for Heat Entrepreneurship-A Case Study of North Karelia, Finland. Energy Policy 2013, 61, 783-787. [CrossRef]

37. Journal of Laws 2021, Item 468, Consolidated Text The Act of May 20, 2016 on Energy Efficiency 2021. Available online: https:/ /isap.sejm.gov.pl/isap.nsf/download.xsp/WDU20160000831/U/D20160831Lj.pdf (accessed on 1 December 2021).

38. Available online: https://mazovia.pl/resource/29298/1753_1011.pdf (accessed on 1 December 2021). 
39. Wiśniewska, M. Adaptation to Climate Change, Cross-Sectional Assessment of 16 Regional Operational Programs and Detailed Descriptions of Priority Axes; Związek Stowarzyszeń Polska Zielona Sieć: Warsaw, Poland, 2016. (In Polish)

40. Consus Carbon Engineering, 2016. Low-Emission Economy Plan for the City of Kielce (In Polish). [online] Kielce: Consus Carbon Engineering. Available online: http://www.um.kielce.pl/gfx/kielce2/userfiles/files/gospodarka-niskoemisyjna/plan_ gospodarki_niskoemisyjnej_dla_miasta_kielce_2.pdf (accessed on 1 December 2021).

41. Garnier, O. D2.6 EU Summary Report Documenting the Collected Information on Recommendations for EPC Markets; EEVS Insight Ltd: London, UK, 2014.

42. SAU. Energy-Saving Investments in Public Utility Buildings_Information on the Audit Results; Supreme Audit Office (Najwyższa izba Kontroli): Warsaw, Poland, 2014. (In Polish)

43. Abdulkadyrov, A.S.; Zhigulina, E.P.; Kovnerev, M.A. A Model for Achieving Comprehensive Efficiency of the Energy Projects Implementation in the Sustainable Development Framework. In Industry Competitiveness: Digitalization, Management, and Integration; Bogoviz, A.V., Ragulina, Y.V., Eds.; Lecture Notes in Networks and Systems; Springer International Publishing: Cham, Switzerland, 2020; Volume 115, pp. 589-595. ISBN 9783030407483.

44. Johansen, J.P.; Isaeva, I. Developing and (Not) Implementing Radical Energy Efficiency Innovations: A Case Study of R\&D Projects in the Norwegian Manufacturing Industry. J. Clean. Prod. 2021, 322, 129077. [CrossRef]

45. Thumann, A.; Woodroof, E.A. How to Finance Energy Management Projects: Solving the "Lack of Capital Problem", 1st ed.; Fairmont Press: Lilburn, GA, USA, 2013; ISBN 9781466571532.

46. Turturean, C. Classifications of Foresight Methods. Anu. Inst. De Cercet. Econ. Gheorghe Zane-Iasi 2011, 20, 113-123.

47. Larsen, P.H.; Goldman, C.A.; Satchwell, A. Evolution of the U.S. Energy Service Company Industry: Market Size and Project Performance from 1990-2008. Energy Policy 2012, 50, 802-820. [CrossRef]

48. Guest, G.; Namey, E.E.; Mitchell, M.L. Collecting Qualitative Data: A Field Manual for Applied Research; SAGE Publications, Ltd: London, UK, 2013; ISBN 9781412986847.

49. Balta-Ozkan, N.; Davidson, R.; Bicket, M.; Whitmarsh, L. Social Barriers to the Adoption of Smart Homes. Energy Policy 2013, 63, 363-374. [CrossRef]

50. Liu, P.; Zhou, Y.; Zhou, D.K.; Xue, L. Energy Performance Contract Models for the Diffusion of Green-Manufacturing Technologies in China: A Stakeholder Analysis from SMEs' Perspective. Energy Policy 2017, 106, 59-67. [CrossRef]

51. Fiorello, D.; Martino, A.; Zani, L.; Christidis, P.; Navajas-Cawood, E. Mobility Data across the EU 28 Member States: Results from an Extensive CAWI Survey. Transp. Res. Procedia 2016, 14, 1104-1113. [CrossRef]

52. Nazarko, J.R.; Ejdys, J.R. Metodologia I Procedury Badawcze W Projekcie Foresight Technologiczny "NT FOR Podlaskie 2020": Regionalna Strategia Rozwoju Nanotechnologii; Oficyna Wydawnicza Politechniki Białostockiej: Białystok, Poland, 2011.

53. Kalhammer, F.R.; Kopf, B.M.; Swan, D.H.; Roan, V.P.; Walsh, M.P. Status and Prospects for Zero Emissions Vehicle Technology; Report of the ARB Independent Expert Panel 2007; State of California Air Resources Board: Sacramento, CA, USA, 2007.

54. EC The European Green Deal Investment Plan and JTM Explained. Available online: https://ec.europa.eu/commission/ presscorner/detail/en/qanda_20_24 (accessed on 27 July 2021).

55. EC Recovery Plan for Europe. Available online: https:/ / ec.europa.eu/info/strategy/recovery-plan-europe_en (accessed on 27 July 2021).

56. EC EU Cohesion Policy 2021-2027. Available online: https://ec.europa.eu/regional_policy/pl/2021_2027/ (accessed on 27 July 2021). 